Artikel Penelitian

\title{
Karakteristik Karsinoma Serviks di RS. Dr. M. Djamil Padang Periode Januari 2010 - Desember 2013
}

\author{
Panji Hadi Permana ${ }^{1}$, Pelsi Sulaini ${ }^{2}$, Noza Hilbertina ${ }^{3}$
}

\begin{abstract}
Abstrak
Peningkatan kasus karsinoma serviks dari tahun ke tahun disebabkan oleh berbagai faktor tetapi lebih dari $90 \%$ kasus karsinoma serviks disebabkan oleh Human Papillomavirus (HPV) onkogenik tipe 16 dan 18. Penyakit ini cenderung menyerang pada wanita usia muda pada saat sekarang. Tujuan penelitian ini adalah melihat bagaimana karakteristik karsinoma serviks dari segi usia, paritas, riwayat pekerjaan, riwayat pekerjaan suami, domisili, gambaran histopatologi dan stadium. Telah dilakukan penelitian deskriptif retrospektif terhadap pasien yang didiagnosis secara histopatologi menderita karsinoma serviks di Bagian Obstetri dan Ginekologi RS. Dr. M. Djamil Padang periode Januari 2010 - Desember 2013 yang Berdasarkan 152 kasus karsinoma serviks didapatkan bahwa kejadian karsinoma serviks berfluktuasi dari Januari 2010 - Desember 2013. Karsinoma serviks terbanyak ditemukan pada pasien yang berusia 45 - 49 tahun, paritas > 2, ibu rumah tangga, bersuami petani, domisili di Padang, jenis histopatologi karsinoma sel skuamosa, moderately differentiated dan stadium IIB. Di negara Indonesia, kasus karsinoma serviks masih banyak ditemukan terutama pada wanita usia muda dan tindakan deteksi dini masih kurang dilakukan. Diperlukan sosialiasi kepada masyarakat untuk melakukan deteksi dini melalui pemeriksaan pap smear dan Inspeksi Visual Asetat (IVA) serta pencegahan dengan vaksin HPV.
\end{abstract}

Kata kunci: karsinoma serviks, usia, paritas, karsinoma sel skuamosa

\begin{abstract}
Cervical carcinoma in rise year - by - year because of many factor, but more than $90 \%$ case of cervical carcinoma caused by oncogenic Human Papillomavirus (HPV) type 16 and 18. This disease tends to affect younger women in the present. The objective of this study was to identify the characteristics of cervical carcinoma based on age, parity, occupational history, husband's occupational history, domicile, histophatology, and stage. This research had done with the method of descriptive based on retrospective observation to patient who diagnosed in a histopatology manner suffering cervical carcinoma at the Obstetric and Gynecology Section of Dr. M. Djamil Hospital Padang on January 1st 2010 - December 31st 2013. From 152 case of cervical carcinoma were found which case of cervical carcinoma is fluctuating from January 1st 2010 - December 31st 2013. Cervical carcinoma were often found to the patients aged 45 - 49 years old, parity > 2, housewife, husband's occupational is farmer, domicile in Padang, histopatology is squamous cell carcinoma, moderately differentiated, and stage IIB. In Indonesia, there are still many cases of cervical carcinoma is found mainly in younger women and early detection measures are lacking done. It need socialization to the community for early detection through pap smear test and Visual Inspection with Acetic Acid (VIA) and prevention with HPV vaccine.
\end{abstract}

Keywords: cervical carcinoma, age, parity, squamous cell carcinoma

Affiliasi penulis: 1. Prodi Profesi Dokter FK Unand (Fakultas Kedokteran Universitas Andalas Padang), 2. Bagian Obstetri dan Ginekologi FK Unand, 3. Bagian Patologi Anatomi FK Unand. Korespondensi: Panji Hadi Permana, Email:

panji_smanten@yahoo.co.id, Telp: 085766484672

\section{PENDAHULUAN}

Karsinoma serviks adalah keganasan yang sering terjadi pada wanita di dunia. Penyakit ini menyerang wanita aktif yang masih muda. ${ }^{1}$ Pada saat 
ini, insiden karsinoma serviks dalam hal morbiditas dan mortalitas belum menunjukkan hasil penurunan yang signifikan. ${ }^{2}$

Kejadian karsinoma serviks yaitu $9 \%$ dari kasus karsinoma pada wanita dan menduduki urutan ketujuh dari keseluruhan jenis karsinoma yang ada di dunia. ${ }^{3}$ Insiden karsinoma ini di dunia adalah 527.624 sedangkan untuk angka mortalitasnya adalah 265.653. Angka prevalensi pada 5 tahun belakangan ini adalah 1.547.161. ${ }^{4}$

Kejadian karsinoma serviks di Asia Tenggara adalah 15,8 per 100.000 populasi wanita dan angka kematiannya adalah 8,3 per 100.000 populasi wanita. ${ }^{5}$ Menurut perkiraan Departemen Kesehatan Republik Indonesia, penderita karsinoma serviks di Indonesia jumlahnya semakin meningkat dan saat ini ada sekitar 200.000 kasus setiap tahunnya. Data dari 13 pusat patologi di Indonesia menunjukkan bahwa karsinoma serviks berada pada urutan pertama di antara semua karsinoma $(23,43 \%$ dari 10 jenis karsinoma dan $31 \%$ dari 10 jenis karsinoma di kalangan wanita). ${ }^{6}$

Karsinoma ini merupakan penyakit ginekologi yang memiliki tingkat keganasan yang cukup tinggi sehingga karsinoma ini menjadi penyebab kematian utama akibat kanker pada wanita di negara-negara berkembang. ${ }^{7}$ Delapan puluh lima persen kejadian karsinoma ini terjadi di negara berkembang. ${ }^{3}$

Kejadian karsinoma serviks ini sering mengenai usia-usia muda. ${ }^{8}$ Di Indonesia, karsinoma serviks merupakan jenis karsinoma yang paling banyak menyerang wanita usia produktif. ${ }^{7}$ Wanita usia produktif adalah usia 15 - 49 tahun. $^{9}$ Wanita yang berusia 30 - 50 tahun dan sudah berkontak seksual akan berisiko tinggi terkena karsinoma serviks. ${ }^{7}$

Penelitian di Inggris yang dilakukan pada wanita yang berusia $20-29$ tahun dan didiagnosis sebagai karsinoma serviks mayoritas pada stadium IA $(62 \%)$. Selain itu, karsinoma serviks jarang terjadi pada umur 20 - 24 (hanya 12\%), sedangkan pada usia 25 tahun berjumlah $24 \%$ dan usia 26-29 tahun berjumlah $63 \%$. $^{10}$

Berdasarkan uraian di atas, penelitian ini bertujuan untuk mengetahui bagaimana karakteristik karsinoma serviks di Bagian Obstetri dan Ginekologi RS. Dr. M. Djamil Padang periode Januari 2010 Desember 2013.

\section{METODE}

Desain penelitian ini adalah deskriptif retrospektif yang dilakukan dengan melihat status rekam medik pasien di bagian Obstetri dan Ginekologi RS. Dr. M. Djamil Padang.

Penelitian telah dilakukan selama Juli sampai Oktober 2014 di Bagian Obstetri dan Ginekologi RS. Dr. M. Djamil Padang. Data sekunder tersebut merupakan data dari Januari 2010 - Desember 2013.

Populasi penelitian ini adalah pasien yang berobat ke Bagian Obstetri dan Ginekologi RS. Dr. M. Djamil Padang selama Januari 2010 - Desember 2013 dan telah didiagnosis karsinoma serviks secara histopatologi. Sampel penelitian adalah semua populasi yang memenuhi syarat kriteria inklusi untuk melakukan penelitian.

Teknik pengambilan sampel adalah total sampling dengan mengambil seluruh sampel yang memenuhi kriteria inklusi mulai dari Januari 2010 Desember 2013.

\section{HASIL}

Telah dilakukan penelitian di Instalasi Rekam Medik RS. Dr. M. Djamil Padang dengan mengumpulkan data sekunder berupa data pasien karsinoma serviks di RS. Dr. M. Djamil Padang periode Januari 2010 - Desember 2013. Berdasarkan data yang diperoleh, didapatkan 152 orang pasien karsinoma serviks di RS. Dr. M. Djamil Padang.

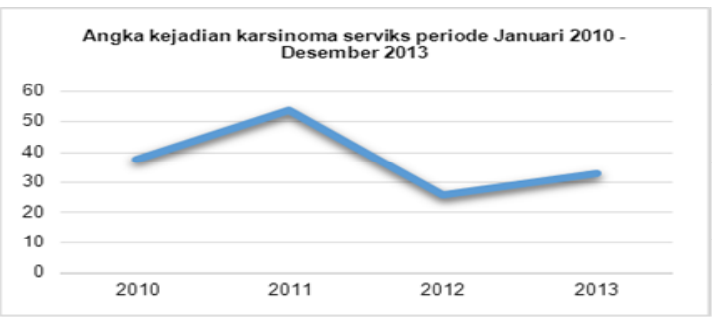

Gambar 1. Angka kejadian karsinoma serviks periode Januari 2010 - Desember 2013

Berdasarkan Gambar 1 dapat dilihat bahwa angka kejadian karsinoma serviks periode Januari 2010 - Desember 2013 berfluktuasi dari tahun ke tahun dan angka kejadian karsinoma serviks tertinggi terjadi pada tahun 2011. 
Tabel 1. Distribusi kejadian karsinoma serviks berdasarkan tahun ditinjau dari segi usia

\begin{tabular}{|c|c|c|c|c|c|c|}
\hline \multirow{2}{*}{ No } & \multirow{2}{*}{ Usia } & \multicolumn{4}{|c|}{ Tahun } & \multirow{2}{*}{ Tota } \\
\hline & & 2010 & 2011 & 2012 & 2013 & \\
\hline 1 & $20-24$ & 0 & 0 & 0 & 0 & 0 \\
\hline 2 & $25-29$ & 0 & 1 & 0 & 0 & 1 \\
\hline 3 & $30-34$ & 3 & 2 & 2 & 1 & 8 \\
\hline 4 & $35-39$ & 7 & 4 & 1 & 2 & 14 \\
\hline 5 & $40-44$ & 6 & 6 & 3 & 6 & 21 \\
\hline 6 & $45-49$ & 9 & 15 & 9 & 9 & 42 \\
\hline 7 & $50-54$ & 8 & 10 & 4 & 6 & 28 \\
\hline 8 & $55-59$ & 0 & 9 & 5 & 6 & 20 \\
\hline 9 & $60-64$ & 0 & 3 & 2 & 3 & 8 \\
\hline 10 & $65-69$ & 5 & 1 & 0 & 0 & 6 \\
\hline 11 & $70-74$ & 0 & 1 & 0 & 0 & 1 \\
\hline 12 & $75-79$ & 0 & 2 & 0 & 0 & 2 \\
\hline 13 & $80-84$ & 0 & 0 & 0 & 0 & 0 \\
\hline \multirow[t]{2}{*}{14} & $85+$ & 0 & 0 & 0 & 0 & 0 \\
\hline & Total & 38 & 54 & 26 & 33 & \\
\hline
\end{tabular}

Berdasarkan Tabel 1 dilihat bahwa mayoritas kejadian karsinoma serviks ditinjau dari segi usia terjadi pada usia 45 - 49 tahun.

\section{Karsinoma serviks ditinjau dari segi paritas}

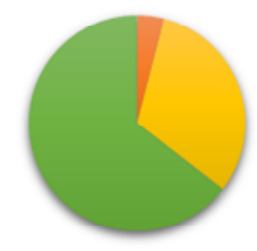

m Tidak ada anak $\|\leq 2 \quad\|>2$

Gambar 2. Karsinoma serviks ditinjau dari segi paritas

Berdasarkan Gambar 2 dapat dilihat bahwa mayoritas pasien karsinoma serviks memiliki anak lebih dari 2 (64,52\%).

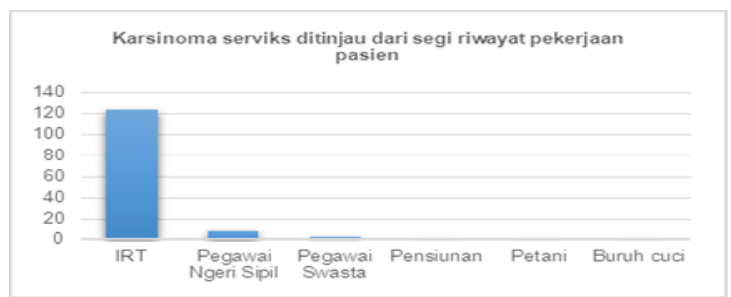

Gambar 3. Karsinoma serviks ditinjau dari segi riwayat pekerjaan pasien
Berdasarkan Gambar 3 dapat dilihat bahwa mayoritas pekerjaan pasien adalah ibu rumah tangga.

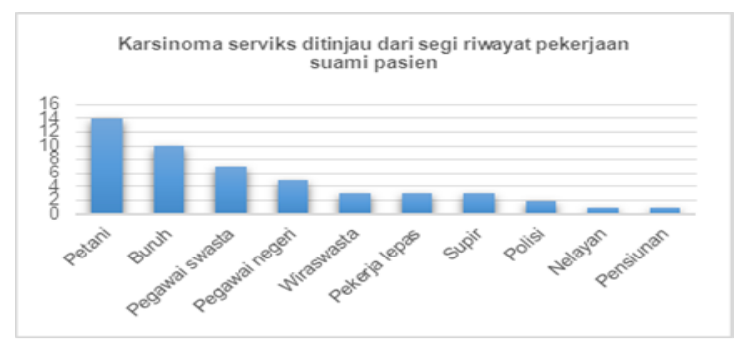

Gambar 4. Karsinoma serviks ditinjau dari segi riwayat pekerjaan suami pasien

Berdasarkan Gambar 4 dapat dilihat bahwa mayoritas pekerjaan suami pasien adalah petani.

Tabel 2.Karsinoma serviks ditinjau dari domisili pasien

\begin{tabular}{|c|c|c|}
\hline Domisili & $\mathbf{f}$ & $\%$ \\
\hline \multicolumn{3}{|l|}{ Sumatera Barat } \\
\hline Kabupaten Agam & 3 & $2,04 \%$ \\
\hline Kabupaten Dharmasraya & 4 & $2,72 \%$ \\
\hline Kabupaten Kepulauan Mentawai & 4 & $2,72 \%$ \\
\hline Kabupaten Lima Puluh Kota & 0 & $0,00 \%$ \\
\hline Kabupaten Padang Pariaman & 3 & $2,04 \%$ \\
\hline Kabupaten Pasaman & 5 & $3,40 \%$ \\
\hline Kabupaten Pasaman Barat & 1 & $0,68 \%$ \\
\hline Kabupaten Pesisir Selatan & 12 & $8,16 \%$ \\
\hline Kabupaten Sijunjung & 0 & $0,00 \%$ \\
\hline Kabupaten Solok & 0 & $0,00 \%$ \\
\hline Kabupaten Solok Selatan & 3 & $2,04 \%$ \\
\hline Kabupaten Tanah Datar & 9 & $6,12 \%$ \\
\hline Kota Bukittingi & 3 & $2,04 \%$ \\
\hline Kota Padang & 58 & $39,46 \%$ \\
\hline Kota Padang Panjang & 1 & $0,68 \%$ \\
\hline Kota Pariaman & 7 & $4,76 \%$ \\
\hline Kota Payakumbuh & 4 & $2,72 \%$ \\
\hline Kota Sawahlunto & 0 & $0,00 \%$ \\
\hline Kota Solok & 8 & $5,44 \%$ \\
\hline \multicolumn{3}{|l|}{ Luar Sumatera Barat } \\
\hline Kabupaten Kerinci & 6 & $4,08 \%$ \\
\hline Kota Jambi & 13 & $8,84 \%$ \\
\hline Bengkulu & 1 & $0,68 \%$ \\
\hline Riau & 1 & $0,68 \%$ \\
\hline Kepulauan Riau & 1 & $0,68 \%$ \\
\hline
\end{tabular}

Berdasarkan Tabel 2 dapat dilihat bahwa mayoritas domisili pasien adalah Padang. 
Karsinoma serviks ditinjau dari segi jenis histopatologi

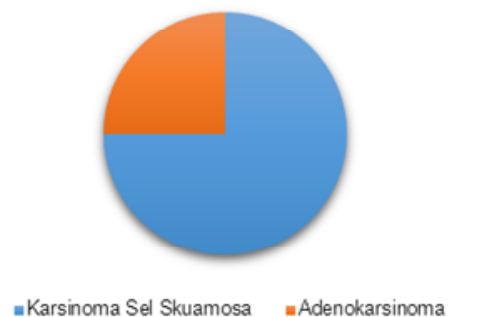

Gambar 5. Karsinoma serviks ditinjau dari segi jenis histopatologi

Berdasarkan Gambar 5 dapat dilihat bahwa mayoritas jenis histopatologi karsinoma serviks adalah karsinoma sel skuamosa.

Tabel 3. Jenis histopatologi karsinoma serviks ditinjau dari segi usia

\begin{tabular}{l|c|c|}
\hline \multirow{2}{*}{ Usia } & \multicolumn{2}{|c}{ Jenis Histopatologi } \\
\cline { 2 - 3 } & $\begin{array}{c}\text { Karsinoma Sel } \\
\text { Skuamosa }\end{array}$ & Adenokarsinoma \\
\hline $20-24$ & 0 & 0 \\
$25-29$ & 1 & 0 \\
$30-34$ & 5 & 0 \\
$35-39$ & 5 & 2 \\
$40-44$ & 9 & 4 \\
$\mathbf{4 5 - 4 9}$ & 17 & 5 \\
$\mathbf{5 0}-\mathbf{5 4}$ & 10 & $\mathbf{6}$ \\
$55-59$ & 11 & 3 \\
$60-64$ & 3 & 0 \\
$65-69$ & 1 & 1 \\
$70-74$ & 0 & 0 \\
$75-79$ & 1 & 0 \\
$80-84$ & 0 & 0 \\
$85+$ & 0 & 0 \\
\hline
\end{tabular}

Berdasarkan Tabel 3 dapat dilihat bahwa mayoritas karsinoma sel skuamosa terjadi pada pasien yang berusia 45 - 49 tahun sedangkan adenokarsinoma terjadi pada pasien yang berusia 50 -54 tahun.
Karsinoma serviks ditinjau dari segi diferensiasi sel tumor

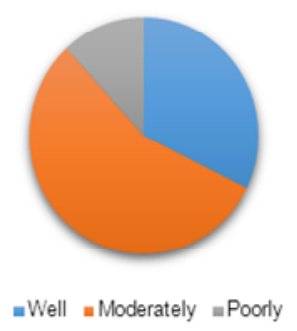

Gambar 6. Karsinoma serviks ditinjau dari segi diferensiasi sel tumor

Berdasarkan Gambar 6 dapat dilihat bahwa mayoritas diferensiasi histopatologi karsinoma serviks adalah moderately differentiated.

Tabel 4. Diferensiasi sel tumor karsinoma serviks ditinjau dari segi usia

\begin{tabular}{lccc}
\hline \multirow{2}{*}{ Usia } & \multicolumn{3}{c}{ Diferensiasi } \\
\cline { 2 - 4 } & Well & Moderately & Poorly \\
\hline $20-24$ & 0 & 0 & 0 \\
$25-29$ & 0 & 1 & 0 \\
$30-34$ & 0 & 3 & 0 \\
$35-39$ & 2 & 2 & 1 \\
$40-44$ & 5 & 4 & 1 \\
$\mathbf{4 5}-\mathbf{4 9}$ & $\mathbf{8}$ & $\mathbf{9}$ & 1 \\
$\mathbf{5 0}-\mathbf{5 4}$ & 4 & 6 & $\mathbf{3}$ \\
$55-59$ & 3 & 8 & 1 \\
$60-64$ & 0 & 3 & 0 \\
$65-69$ & 0 & 1 & 1 \\
$70-74$ & 0 & 0 & 0 \\
$75-79$ & 0 & 1 & 0 \\
$80-84$ & 0 & 0 & 0 \\
$85+$ & 0 & 0 & 0 \\
\hline
\end{tabular}

Berdasarkan Tabel 4 dapat dilihat bahwa mayoritas jenis well dan moderately differentiated terjadi pada pasien karsinoma serviks yang berusia 45 - 49 tahun (8 kasus well differentiated dan 9 kasus moderately differentiated) sedangkan poorly differentiated terjadi pada pasien karsinoma serviks yang berusia 50 - 54 tahun dengan jumlah 3 kasus. 
Tabel 5. Stadium karsinoma serviks ditinjau dari usia

\begin{tabular}{|c|c|c|c|c|c|c|c|c|c|}
\hline \multirow{2}{*}{ Usia } & \multicolumn{9}{|c|}{ Stadium } \\
\hline & 0 & IA & IB & IIA & IIB & IIIA & IIIB & IVA & IVB \\
\hline $\begin{array}{l}20- \\
24\end{array}$ & 0 & 0 & 0 & 0 & 0 & 0 & 0 & 0 & 0 \\
\hline $\begin{array}{l}25- \\
29\end{array}$ & 0 & 0 & 0 & 0 & 1 & 0 & 0 & 0 & 0 \\
\hline $\begin{array}{l}30- \\
34\end{array}$ & 0 & 0 & 1 & 0 & 3 & 1 & 0 & 1 & 0 \\
\hline $\begin{array}{l}35- \\
39\end{array}$ & 0 & 1 & 1 & 0 & 5 & 3 & 0 & 3 & 0 \\
\hline $\begin{array}{l}40- \\
44\end{array}$ & 0 & 0 & 1 & 0 & 4 & 2 & 7 & 3 & 0 \\
\hline $\begin{array}{l}45- \\
49\end{array}$ & 0 & 0 & 1 & 7 & 12 & 4 & 5 & 4 & 2 \\
\hline $\begin{array}{l}50- \\
54\end{array}$ & 0 & 1 & 1 & 4 & 5 & 5 & 3 & 4 & 1 \\
\hline $\begin{array}{l}55- \\
59\end{array}$ & 0 & 0 & 1 & 3 & 3 & 1 & 3 & 0 & 0 \\
\hline $\begin{array}{l}60- \\
64\end{array}$ & 0 & 0 & 0 & 2 & 1 & 1 & 1 & 0 & 0 \\
\hline $\begin{array}{l}65- \\
69\end{array}$ & 0 & 0 & 0 & 0 & 0 & 0 & 2 & 2 & 0 \\
\hline $\begin{array}{l}70- \\
74\end{array}$ & 0 & 0 & 0 & 0 & 0 & 0 & 0 & 0 & 0 \\
\hline $\begin{array}{l}75- \\
79\end{array}$ & 0 & 0 & 0 & 0 & 0 & 0 & 0 & 1 & 0 \\
\hline $\begin{array}{l}80- \\
84\end{array}$ & 0 & 0 & 0 & 0 & 0 & 0 & 0 & 0 & 0 \\
\hline $85+$ & 0 & 0 & 0 & 0 & 0 & 0 & 0 & 0 & 0 \\
\hline
\end{tabular}

Berdasarkan Tabel 5 dapat dilihat bahwa mayoritas stadium pasien karsinoma serviks di RS. Dr. M. Djamil adalah stadium IIB. Mayoritas stadium IIB tersebut terjadi pada pasien karsinoma serviks yang berusia $45-49$ tahun.

\section{PEMBAHASAN}

Angka kejadian karsinoma serviks terbanyak terjadi pada tahun 2011 yaitu 55 kasus sedangkan pada tahun 2010 angka kejadian karsinoma serviks 38 kasus, pada tahun 2012 angka kejadian karsinoma serviks 26 kasus, dan pada tahun 2013 angka kejadian karsinoma serviks 33 kasus. Data ini menggambarkan bahwa kejadian karsinoma serviks berfluktuasi dari tahun ke tahun.

Hasil yang berbeda didapatkan di Amerika Serikat bahwa insiden karsinoma serviks telah banyak berkurang sejak tahun 1930 - an dan kasusnya turun secara drastis semenjak diperkenalkannya teknik skrining pap smear oleh Papanicolaou. Namun, hingga saat ini program skrining belum lagi memasyarakat di negara berkembang, hingga mudah dimengerti mengapa insiden karsinoma serviks masih tetap tinggi. ${ }^{11}$

Mayoritas penderita karsinoma serviks datang berobat pada umur 45 - 49 tahun pada tahun 2010 , 2011, 2012, dan 2013. Data ini memperlihatkan bahwa penderita karsinoma serviks yang berobat di RS. Dr. M. Djamil masih berusia produktif. Wanita usia produktif adalah usia 15 - 49 tahun. $^{9}$ Karsinoma serviks banyak diderita oleh wanita usia produktif yakni usia 15 - 49 tahun sebanyak 86 kasus. Hal ini sesuai dengan kepustakaan bahwa karsinoma serviks ini timbul pada wanita usia produktif dengan insidensi pucak pada usia sekitar 45 tahun, sekitar 10 hingga 15 tahun setelah deteksi prekursornya. ${ }^{12}$ Berdasarkan data di RSUP Adam Malik Medan didapatkan bahwa kejadian karsinoma serviks terbanyak pada usia 40 55 tahun yaitu sebanyak 214 pasien. ${ }^{13}$

Pasien karsinoma serviks mempunyai anak $>2$ orang (multipara) didapatkan 80 kasus. Berdasarkan data ini dapat diperhatikan bahwa mayoritas pasien multipara yang mengalami karsinoma serviks. Berdasarkan data di RSUP Adam Malik, pasien karsinoma serviks juga banyak diderita pada paritas yang $>2$ anak yaitu sebanyak 206 pasien. ${ }^{13}$ Paritas yang tinggi berisiko untuk menjadi karsinoma serviks. $^{14}$

Kebanyakan pekerjaan pasien karsinoma serviks adalah ibu rumah tangga sebanyak 124 orang sedangkan pekerjaan suaminya adalah petani sebanyak 14 orang. Dari 124 orang ibu rumah tangga itu terdapat 49 orang yang mencantumkan pekerjaan suaminya dan dari 49 pasien tersebut mayoritas pekerjaan suaminya adalah petani yaitu 14 orang.

Wanita miskin berisiko untuk terjadinya karsinoma serviks karena asupan gizi dan nutrisi yang kurang memadai sehingga kekebalan tubuhnya lemah melawan virus. Ekonomi yang rendah akan menyebabkan tingkat pendidikan menjadi rendah dan hal itu berkaitan dengan masih kurangnya skrining karsinoma serviks. Masyarakat ini mempunyai keterbatasan akses untuk melakukan skrining sehingga program pap smear sangat dibutuhkan di lingkungan ini. ${ }^{14}$

Pasien karsinoma serviks terbanyak berdomisili di Padang sebanyak 58 orang. Hal ini menggambarkan bahwa pasien karsinoma serviks di RS. Dr. M. Djamil kebanyakan dari kota Padang dan ini mungkin disebabkan karena lokasi penelitian yang terletak di RS. Dr. M. Djamil yang berlokasi di Padang dan RS. Dr. M. Djamil dijadikan sebagian pusat rujukan kasus ini. Akses untuk ke rumah sakit juga 
lebih besar berkesempatan bagi pasien yang berada di kota Padang daripada pasien yang berada di desa sehingga kebanyakan pasien berasal dari kota Padang untuk RS. Dr. M. Djamil.

Jenis histopatologi pada pasien karsinoma serviks ini terbanyak adalah karsinoma sel skuamosa dibanding dengan adenokarsinoma dan jumlah pasien yang tidak memiliki data jenis histopatologi adalah 68 pasien. Delapan puluh lima persen jenis histopatologi karsinoma serviks adalah karsinoma sel skuamosa dan $15 \%$ adenokarsinoma. ${ }^{15}$

Mayoritas karsinoma jenis sel skuamosa ditemukan pada usia 45 - 49 tahun dan adenokarsinoma pada usia 50 - 54 tahun. Karsinoma sel skuamosa lebih cepat terdiagnosa daripada adenokarsinoma dan berdasarkan data tentang usia karsinoma serviks, tergambar bahwa karsinoma serviks sering terjadi pada usia $45-49$ tahun. Kasus adenokarsinoma tersebut masih jarang ditemukan cepat karena letaknya yang tersembunyi sehingga jarang menimbulkan gejala klinis yang khas. Kasus adenokarsimona pada usia berapapun itu tersebar merata. ${ }^{15}$

Sebagian besar diferensiasi histopatologi karsinoma serviks adalah tipe moderately dengan 38 kasus. Sekitar $70 \%$ mereka datang dengan kondisi stadium lanjut sehingga karsinoma serviks sering ditemukan dalam bentuk moderately. ${ }^{16}$

Jenis well dan moderately differentiated sering terjadi pada pasien karsinoma serviks yang berusia 45 - 49 tahun (8 kasus well differentiated dan 9 kasus moderately differentiated) sedangkan poorly differentiated terjadi pada pasien karsinoma serviks yang berusia 50 - 54 tahun dengan jumlah 3 kasus. Berdasarkan data ini menggambarkan bahwa tipe well dan moderately lebih sering terjadi pada wanita usia produktif dibanding dengan poorly dan tipe poorly lebih banyak ditemukan pada usia tidak produktif yaitu 50 54 tahun. Tujuannya di sini adalah untuk melihat bagaimana terapi yang bisa dilakukan dan prognosis untuk pasien karsinoma serviks. Diferensiasi sel tumor ini berguna untuk mengindikasikan bagaimana kecepatan pertumbuhan tumor sediri dan penyebarannya. Umumnya, well differentiated mengindikasikan prognosis yang lebih baik dan karsinoma dengan diferensiasi yang tinggi bisa tumbuh dan menyebar dengan cepat dan memerlukan pengobatan yang segera. ${ }^{17}$

Stadium pasien karsinoma serviks di RS. Dr. M. Djamil paling banyak adalah stadium IIB dengan jumlah 35 kasus dan jumlah pasien yang tidak memiliki data stadiumnya adalah 35 pasien. Kebanyakan pasien karsinoma serviks datang ke rumah sakit dengan stadium IIB dan angka kelangsungan hidupnya adalah $73,3 \%{ }^{18}$ Stadium IIB tersebut terjadi pada pasien karsinoma serviks RS. Dr. M. Djamil yang berusia $45-49$ tahun dengan jumlah 12 kasus. Hal ini dimungkinkan berkaitan dengan tingkat pendidikan yang masih rendah sehingga pengetahuan tentang deteksi dini karsinoma serviks masih rendah.

\section{SIMPULAN}

Usia terbanyak pasien karsinoma serviks ditemukan pada rentang usia 45 - 49 tahun.

Kasus karsinoma serviks terbanyak ditemukan pada pasien dengan paritas $>2$ anak.

Pekerjaan pasien karsinoma serviks terbanyak adalah sebagai ibu rumah tangga.

Riwayat pekerjaan suami pasien karsinoma serviks adalah sebagai petani.

Domisili pasien karsinoma serviks terbanyak adalah Padang.

Jenis histopatologi karsinoma serviks terbanyak pada pasien karsinoma serviks adalah jenis karsinoma sel skuamosa. Kasinoma sel skuamosa terbanyak ditemukan pada paien berusia 45 - 49 tahun dan adenokarsinoma terbanyak ditemukan pada pasien berusia 50 - 54 tahun. Jenis diferensiasi karsinoma terbanyak ditemukan dalam bentuk moderately. Jenis well dan moderately differentiated terbanyak ditemukan pada pasien berusia 45 - 49 tahun sedangkan jenis poorly differentiated ditemukan pada pasien berusia $50-54$ tahun.

Stadium pasien karsinoma serviks terbanyak ditemukan pada stadium IIB dan stadium IIB terbanyak ditemukan pada pasien berusia 45 - 49 tahun.

\section{SARAN}

Mengingat karena masih tingginya kejadian karsinoma serviks maka perlu dilakukan peningkatan upaya deteksi dini karsinoma serviks. 


\section{UCAPAN TERIMA KASIH}

Terima kasih kepada semua pihak atas masukan dalam penyelesaian penelitian ini.

\section{DAFTAR PUSTAKA}

1. Kyrgiou M, Shafi MI. Invasive cancer of the cervix. Obstetrics, Gynecologic, and Reproductive Medicine. 2013;23(11):343-51.

2. Suryapratama SA. Karakteristik penderita kanker serviks di RSUP Dr. Kariadi Semarang tahun 2010. (skripsi). Semarang: Fakultas Kedokteran Universitas Diponegoro; 2012.

3. Freitas. Suspectibility to cervical cancer. Gynecologic Oncologic. 2013;126:304-11.

4. Thomas AC. Estimated cancer incidence, mortality, and prevalence worldwide in 2012. International Agency for Research on Cancer; 2014.

5. Cancer Research United Kingdom. Cervical cancer incidence statistics. England and Wales; 2014.

6. Nuranna L, Aziz MF, Cornain S, Purwoto G, Purbadi S.Cervical cancer prevention program in Jakarta. Journal of Gynecologic Oncology. 2012; 23(3):147-52.

7. Fitriana NA, Ambarini TK. Psikologi klinis dan kesehatan mental. Surabaya: Fakultas Psikologi Universitas Airlangga; 2012.

8. Manuaba IB. Dasar-dasar teknik operasi ginekologi. Jakarta: EGC; 2004.
9. BkkbN. Batasan dan pengertian mutakhir data keluarga. Jakarta: BkkbN; 2011.

10. Castanon A, Leung VM, Landy R, Lim AW, Sasieni $P$. Characteristics and screening history of women diagnosed with cervical cancer aged 20-29 years. British Journal of Cancer. 2013;109:35-41.

11. Edianto D. Kanker serviks. Jakarta: Yayasan Bina Pustaka Sarwono Prawirodihardjo; 2006.

12. Robbin SL, Cotran RS, Kumar V. Sistem genitalia perempuan dan payudara. Buku ajar patologi jilid 2 (terjemahan). Edisi ke-7 Jakarta: EGC; 2007. hlm.765-70.

13. Prandana. Pasien kanker serviks di RSUP Adam Malik tahun 2011 (skripsi). Medan: Fakultas Kedokteran Universitas Sumatera Utara; 2013.

14. Williams. Cervical cancer. Singapore: McGraw-Hill Companies; 2012.hlm.769-89.

15. Lestadi J. Sitologi neoplasma. Jakarta: EGC; 2009.hlm.62-89.

16. Romadhoni, Yazid N, Aviyanti D. Penyerapan pengetahuan tentang kanker serviks sebelum dan sesudah penyuluhan (skripsi). Fakultas Kedokteran Universitas Muhammadiyah; 2012.

17. National Cancer Institue. Tumor grade. USA: National Institue of Health; 2010.

18. Hacker NF. Cervical dysplasia and cancer. Elsevier: Hippocrates; 2004.hlm.447-58. 